Article

\title{
Peptide-Based Formulation from Lactic Acid Bacteria Impairs the Pathogen Growth in Ananas Comosus (Pineapple)
}

\author{
Gabriela N. Tenea *(D), Daniela Olmedo and Clara Ortega \\ Biofood and Nutraceutics Research and Development Group, Faculty of Engineering in Agricultural and \\ Environmental Sciences, Technical University of the North, Ibarra 100150, Ecuador; \\ deolmedof@utn.edu.ec (D.O.); cgortega@utn.edu.ec (C.O.) \\ * Correspondence: gntenea@utn.edu.ec; Tel.: +593-6-2997800
}

Received: 25 March 2020; Accepted: 15 April 2020; Published: 9 May 2020

check for updates

\begin{abstract}
Worldwide, street vending commerce has grown exponentially, representing in some countries, including Ecuador, a significant proportion of food consumed by the urban population. Pineapple is one of the common fruits sold as ready-to-eat slices by ambulant vendors in the street or on public transport at risk of contamination by various microorganisms. Previously, we selected Lactobacillus plantarum UTNCys5-4 and Lactococcus lactis subsp. lactis Gt28 strains producing peptides with high capacity to inhibit pathogen growth in vitro. In this study, the effect of different edited formulations containing a mixture of Cys5-4/Gt28 peptides was evaluated in vitro and ex vitro against a pathogenic cocktail containing E. coli (2), Salmonella (2) and Shigella (1). The growth of bacterial cocktail co-inoculated with cell-free supernatant containing peptides (formulation T1) and precipitated peptides (formulation T6), in a ratio of Cys5-4/Gt28:1:1 (v/v), results in a decrease of total cell viability with 1.85 and $1.2 \log \mathrm{CFU} / \mathrm{mL}$ orders of magnitude at $6 \mathrm{~h}$ of incubation. About the same decrease (1.9 log CFU/g) was observed when pineapple slices artificially inoculated with the pathogenic cocktail were coated with $\mathrm{T} 1$ formulation, indicating the capacity to diminish simultaneous pathogens in situ, thus demonstrating its great biological control and protection. However, the E. coli cell counts reduced by $2.08 \log$ CFU/g while Salmonella and Shigella cell counts reduced by 1.43 and $1.91 \log \mathrm{CFU} / \mathrm{g}$, respectively, at 5 days of refrigeration. In the untreated pineapple slices, the total cell density was maintained during storage, suggesting the adaptation of the pathogens to the fruit matrix. The peptide-based formulation exerted a bacteriolytic mode of action inducing pathogenic cell death. The results indicate that coating pineapple slices with peptide-based formulation is a promising approach to protect them from further contamination by microbial spoilage as well as an alternative to increase the food safety.
\end{abstract}

Keywords: peptides; lactic acid bacteria; pineapple; antimicrobial; bacteriolytic; TEM

\section{Introduction}

Pineapple (Ananas comosus) is the third most commonly consumed fruit in Ecuador, after bananas and citrus fruits [1]. This perennial herbaceous fruit is produced in several provinces, including Guayas, Los Ríos, Santo Domingo, El Oro, Esmeraldas and Manabí [1,2]. The fruit is mainly consumed as juice, salad, or ready-to eat fresh slices or chunks [3]. Once cut, fruits provide a suitable ecosystem for microbial growth and survival; thus, microbiological safety is of concern. Since the freshly cut chunks are perishable, they need immediate conservation treatment to reduce the microbial growth [4]. Selling foods in the street or on public transport is a cultural behavior in Ecuador. Approval and inspection of pineapple sold in this manner is basically non-existent. Human hygiene, post-harvest 
manipulation and inappropriate storage are the principal sources of contamination of fruits in general. Although pineapple has low $\mathrm{pH}$ (3.7-3.8) and very active proteases (e.g., bromelain), it is susceptible to outbreaks of pathogens such as Salmonella spp., E. coli spp. and Shigella spp. [5]. Pathogens present in food systems can cause disease; thus, their selective elimination by introducing small changes in the normal niche of fruits with bacterial cells or their derivates might be a suitable solution to be considered. Natural protection using microorganisms such lactic acid bacteria (LAB) or their antimicrobial components (bacteriocins) for food protection has been gaining interest, since they are classified as "generally recognized as safe" and have shown antimicrobial capacities; additionally, it is considered an environmentally friendly method [6,7]. Nonetheless, nisin (E-234), produced by Lactococcus lactis, remains the only polypeptide antibacterial substance or bacteriocin approved by the Food and Agriculture Organization to be used as food additive [8]. Moreover, LAB can survive under cold storage temperatures, and their fermentation products or purified metabolites can be used as food additives [9]; they reduce mesophilic aerobic counts in a similar form as chlorine. LAB strains isolated from fresh vegetables showed antimicrobial activity against Staphylococcus aureus [10]. Early research showed that by introducing LAB in fresh foods, the growth of pathogenic microorganisms is reduced considerably [11]. Recently, we investigated the antimicrobial capacity of LAB isolated from wild-type fruits of the Amazonian rainforest [12,13]. Among them, some strains such as Lactobacillus plantarum UTNCys5-4 and Lactococcus lactis subsp. lactis Gt28 were proved to produce peptides in situ with high capacity to diminish the pathogens during storage or to prevent their growth; nonetheless, the favorable outcome depends on several characteristics of the producer strain culture, including its technical effectiveness, persistence and commercial viability, its capacity to secrete inhibitory substances, the dose applied as well as the developmental stage of the pathogenic population (early or exponential phase) $[14,15]$. Antimicrobial peptides secreted by both strains are multifaceted substances, which are heat and acid resistant, with complex mechanisms of action, including membrane permeabilization, cell lysis and interaction with internal targets related to DNA and RNA molecules.

In this study, the effect of different edited formulations containing a mixture of Cys5-4/Gt28 peptides applied as cell-free supernatant (CFS) and precipitated peptide (PP) was evaluated in vitro against a pathogenic cocktail containing E. coli ATCC25922, E. coli UTNEc1, Salmonella enterica subsp. enterica ATCC51741, Salmonella UTNSm2 and Shigella sonnei ATCC25931. The combination showing the highest effectiveness in reducing the pathogen population was applied ex vitro in pineapple fruit slices to control their growth for further use as a natural preservative agent. Moreover, using transmission electron microscope (TEM) assay and SDS-PAGE, the mode of action of the selected peptide-based formulation against Salmonella was investigated.

\section{Materials and Methods}

\subsection{Bacterial Strains and Growth Conditions}

Lactobacillus plantarum UTNCys5-4 (GenBank accession No. KY041686.1) and Lactococcus lactis subsp. lactis UTNGt28 (GenBank accession No. MG675576.1) previously isolated and characterized were routinely grown in MRS broth (Difco ${ }^{\text {TM }}$, Detroit, MI, USA). The indicator strains E. coli ATCC25922, E. coli UTNEc1 (lab collection, isolated from fresh cheese), Salmonella enterica subsp. enterica ATCC51741, Salmonella UTNSm2 (lab collection, isolated from cooked chicken) and Shigella sonnei ATCC25931 were grown in Luria-Bertani (Difco ${ }^{\mathrm{TM}}$, Detroit, MI, USA) and nutrient broth culture media.

\subsection{Cell-Free Supernatant (CFS) and Partially Purified Peptides Preparation}

Briefly, the LAB strains grown in MRS broth at $37^{\circ} \mathrm{C}$ for $24 \mathrm{~h}$ were used to extract CFS by centrifugation at $13,000 \times g$ for $30 \mathrm{~min}\left(4^{\circ} \mathrm{C}\right)$. The supernatant was filtered using a $0.22 \mu \mathrm{m}$ porosity syringe filter (cat \# STF020025H, Chemlab Group, Barcelona, Spain). To obtain partially purified peptides, $60 \%$ ammonium sulphate was added to CFS followed by overnight incubation with refrigeration without stirring and centrifuged at $8000 \times g$ for $30 \mathrm{~min}$ and $4{ }^{\circ} \mathrm{C}$. The PP were recovered 
in $25 \mathrm{mM}$ ammonium acetate (pH 6.5), desalted by using a midi dialysis kit (cat \# PURD10005-1KT, Sigma-Aldrich Co. LLC, Saint Louis, MO, USA) pre-equilibrated with phosphate buffer ( $\mathrm{pH} 7.0$ ) and stored at $-20^{\circ} \mathrm{C}$ before use in antimicrobial assays. Titer estimated as $\mathrm{AU} / \mathrm{mL}$ is defined as the highest dilution that inhibited the growth of the indicator strain [14].

\subsection{Peptide-Based Formulations Editing}

The CFS extracted from each bacterial strain (Cys5-4 and Gt28) was used to edit the: (a) CFS peptide-containing formulations as follows: (1) formulation T1: 1:1 (v/v) consisting of $1 \times$ MIC CFSCys5-4 (6400 AU/mL) and $1 \times$ MIC CFSGt28 (6400 AU/mL); (2) formulation T2: 1:3 (v/v) of CFSCys5-4 and CFSGt28; (3) formulation T3: 3:1 (v/v) CFSCys5-4 and CFSGt28; (4) formulation T4, CFSCys5-4 only; (5) formulation T5, CFSGt28 only; (b) PP-based formulations (6) formulation T6: 1:1 $(v / v)$ consisting of $1 \times$ MIC, PPCys5-4 $(6400 \mathrm{AU} / \mathrm{mL})$ and $1 \times$ MIC, PPGt28 $(6400 \mathrm{AU} / \mathrm{mL}) ;(7)$ formulation T7: 1:3 (v/v) PPCys5-4 and PPGt28; (8) formulation T8: 3:1 (v/v) of PPCys5-4 and PPGt28; (9) formulation T9, PPCys5-4 only; (10) formulation T10, PPGt28 only; (11) control (-): fruit slices, no pathogens, no peptide and (12) control (+): fruit slices treated with indicator cocktail.

\subsection{The Effect of Peptide-Based Formulation on Total Cell Viability In Vitro}

Each peptide-based formulation was used in vitro to evaluate its effect on indicator cocktail growth consisting of a mixture of the five indicator bacteria described above. Each indicator strain was grown in appropriate media to reach a cell density of 1.0 (OD605) then washed with distillate water and mixed to obtain the cocktail for further co-inoculation with the peptide-based formulations. Untreated indicator cell mixture was used as control. Incubation was performed at $37^{\circ} \mathrm{C}$ for $6 \mathrm{~h}$, and the cell viability was determined at various intervals $(0,1,3$ and $6 \mathrm{~h})$ using the plate-agar method (BD Difco ${ }^{\mathrm{TM}}$ plate count agar, Fisher Scientific Co. LLC, Hampton, NH, USA). The results were analyzed by determining Log reduction calculated as the difference between $\log$ CFU/mL (CFS peptide-containing or PP-based formulation) of the untreated cells (no peptide added) and the treated cells (peptide added). $\log \mathrm{CFU} / \mathrm{mL}$ reduction of $<1$ was considered insignificant. The formulations that showed highly inhibitory effects were selected for further use ex vitro.

\subsection{Co-Inoculation of Fresh-Cut Pineapple Slices with Indicator Cocktail and Peptide-Based Formulations}

The pineapple fruits were purchased from a local vendor, washed with $5 \%$ bleach solution for $5 \mathrm{~min}$ then twice with distillate water and left to dry under a laminar flow cabinet. The fruit peel was discarded, and the pulp was cut manually with steel equipment into several slices of $25 \mathrm{~g}$. Pineapple slices $(5 \times 25 \mathrm{~g}$ each treatment) were submerged in $200 \mathrm{~mL}$ of the bacterial inoculum cocktail $\left(10^{8} \mathrm{CFU} / \mathrm{mL}\right)$ and rotated by stirring with a glove-covered hand for $10 \mathrm{~min}$ to ensure that bacteria penetrated the fruits, followed by air drying for $3 \mathrm{~h}$ in a biosafety cabinet. The selected coating formulations were used to immerse the fruit slices, manually rotating each slice for $5 \mathrm{~min}$ to assure complete coverage and contact of surfaces with the coating solution, and they were then left to dry for $4 \mathrm{~h}$ under the biosafety cabinet. The fruit slices were packed in food trays covered with plastic food film then stored for 5 days with refrigeration. Pineapple slices washed with sterile water with no formulation added and no cocktail (negative control) and pineapple slices inoculated with bacterial cocktail but with no formulation added (positive control) were used as control.

\subsection{Determination of the Total Cell Viability, pH and Acidity in Pineapple Slices during Storage}

For microbiological enumeration of total cell counts of the inoculated bacterial cocktail with and without peptide added, pieces of pineapple of each treatment were weighed ( $25 \mathrm{~g} /$ each treatment) and placed in peptone water $(0.1 \%)$ for $4 \mathrm{~h}$ at $37^{\circ} \mathrm{C}$, and a serial dilution (1:10) with saline solution $(\mathrm{NaCl} 8.6 \mathrm{~g} / \mathrm{L})$, was used to determine total cell counts by plating on nutrient agar after incubation at $37^{\circ} \mathrm{C}$ for $48 \mathrm{~h}$. The analysis was performed for 5 days using the same strategy. Independently, decimal dilutions $(0.1 \mathrm{~mL})$ were plated in triplicate on chromocult agar culture media to detect and 
enumerate E. coli and SS (Salmonella/Shigella) agar and to discriminate and enumerate Salmonella and Shigella cells. The experiment was repeated three times using pineapple fruits purchased from the same distributer. The results were expressed by determining Log reduction calculated as the difference between $\log \mathrm{CFU} / \mathrm{g}$ of the untreated pineapple slices (no peptide added) and the treated counterpart (peptide formulation added). $\log \mathrm{CFU} / \mathrm{g}$ reduction of $<1$ was considered insignificant. The $\mathrm{pH}$ was monitored daily during fruit storage using a pH meter (S210, Mettler Toledo, Columbus, OH, USA). Total acidity, expressed as a percent of citric acid, was determined daily by titrating of fruit juice (treated and not treated with peptide formulation) with $0.01 \mathrm{~N} \mathrm{NaOH}$ to $\mathrm{pH} 8.2$ as described [16].

\subsection{Effect of T1 and T6 Formulations on Whole Cell Proteins Profile of the Target Salmonella Cells}

The whole cell protein profile of Salmonella enterica subsp. enterica ATCC51741 after treatment with $\mathrm{T} 1$ and T6 was analyzed using the SDS-PAGE method as previously described [12]. Briefly, the cocktail of indicator cells was centrifuged at $3000 \mathrm{rpm}$ and washed twice with $1 \times \mathrm{PBS}$ buffer (pH 7.4). The cell pellet was suspended in $1 \times$ SDS-PAGE loading buffer, boiled for $5 \mathrm{~min}$ at $100{ }^{\circ} \mathrm{C}$ and centrifuged at $300 \mathrm{rpm}$. The supernatants of treated and untreated cells with T1/T6 formulations were used in SDS-PAGE electrophoresis. The tricine-SDS-PAGE method using RunBlue Bis-Tris protein gels (12\%) and Dual Cool Mini vertical PAGE/blotting Systems (Expedeon, Abcam, Cambridge, MA, USA) was used. The gel was stained with InstantBlue ${ }^{\mathrm{TM}}$ ready-to-use stain (Expedeon, Abcam, Cambridge, MA, USA) using a protocol recommended by the manufacturer.

\subsection{Effects of T6 Formulation on the Salmonella Cells under Transmission Electron Microscope (TEM)}

Bacteria without addition of $\mathrm{T} 6$ was prepared and used as a negative control; the T6 formulation was washed away thrice by using sodium phosphate buffer and centrifuging at $10,000 \times g$ for $15 \mathrm{~min}$. The cells were fixed with $2.5 \%$ glutaraldehyde and stored overnight at $4{ }^{\circ} \mathrm{C}$. The protocol used was developed by the Laboratory of Electronic Microscopy, University of Antioquia (Medellin, Colombia). Briefly, the samples were washed thrice with cacodylate buffer and post-fixed for $1 \mathrm{~h}$ with osmium tetroxide $1 \%$ and cacodylate buffer in a 1:1 ratio. Then, they were washed thrice in cacodylate buffer (10 $\mathrm{min}$ ) and incubated overnight in the same buffer. The samples were then washed thrice with water, once with uranyl acetate and again thrice with water. The samples were dehydrated in a graded ethanol series and embedded in Epon (resin). Ultrathin sections were prepared and coated on copper grids and stained with uranyl acetate and lead citrate. The grids (10 random sections per treatment) were examined using the Tecnai G2 F20 transmission electron microscope (FEI Company, Hillsboro, OR, USA). Untreated Salmonella cells were used as control.

\subsection{Statistical Analysis}

All experiments were performed in triplicate; the results were expressed as mean \pm standard deviation. Analysis of variance was applied with Tukey's test to determine the significant differences between the means (SPSS version 15.0).

\section{Results}

\subsection{Designed Peptide-Based Formulations Showed Inhibitory Activity against Target Indicator Strains In Vitro}

With the aim of diminishing several foodborne microorganisms simultaneously, in this study various peptide-based formulations using different doses of Cys5-4 and Gt28 applied in vitro as CFS or PP form were edited, and their effect on a cocktail containing five microorganisms was evaluated. The addition of CFS peptide-containing formulations to the microbial cocktail suspension at the logarithmic phase growth resulted in a decrease of the cell density over $6 \mathrm{~h}$ of incubation. Among the five formulations having different doses of peptide released by Cys5-4 and Gt28 strains, the T1 formulation containing CFS Cys5-4/CFS GT28 with a ratio of 1:1 ( $v / v)$ showed a significant decrease $(p<0.05)$ in microbial population and $1.85 \log \mathrm{CFU} / \mathrm{mL}$ order of magnitude compared to the positive 
control without peptide at $6 \mathrm{~h}$ of incubation (Figure 1). The formulations T2, T3 and T5 showed similar levels of cell viability reduction $(1 \log \mathrm{CFU} / \mathrm{mL})$, while $\mathrm{T} 4$ had marginal inhibitory activity towards indicator cocktail strains. The results indicate that increasing the dose of peptide does not result in a superior inhibitory activity. Similarly, the addition of PP-based formulations results in a decrease in cell viability by 1.2 and $1.0 \log \mathrm{CFU} / \mathrm{mL}$ orders of magnitude for T6 and T7, respectively, while a marginal effect was shown with T8, T9 and T10 (Figure 1). Based on this result, the T1 and T6 formulations, the most effective in cell reduction, were selected for further use ex vitro.

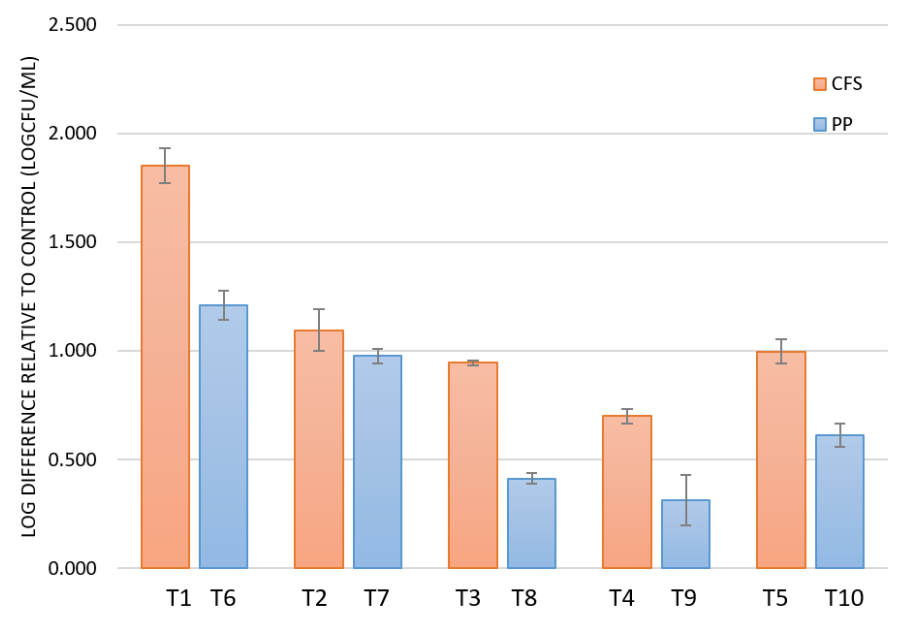

Figure 1. Log difference in cell viability between cell-free supernatant (CFS) peptide-containing formulations and precipitated peptide (PP)-base formulations relative to control (positive, cocktail only) without peptide added. Legend: T1: CFSCys5-4/CFSGt28:1:1 (v/v); T2: CFSCys5-4/CFSGt28:1:3 (v/v); T3: CFSCys5-4/CFSGt28:3:1 (v/v); T4/CFSCys5-4 only; T5: CFSGt28 only; T6: PPCys5-4/PPGt28:1:1 (v/v); T7: PPCys5-4/PPGt28:1:3 (v/v); T8: PPCys5-4/PPGt28:3:1 (v/v); T9: PPCys5-4 only; T10: PPGt28 only.

\subsection{Coating Pineapple Slices with Peptide-Based Formulations Diminished the Target Indicator Cell Growth}

A significant decrease $(p<0.05)$ in cell density of the total indicator microorganisms (5) was observed in the pineapple slices co-inoculated with T1 and T6 formulations, indicating the capacity of coating formulations to simultaneously diminish several pathogens in situ (Figure 2). The maximum reduction of cell density was registered at day 4 at 2.01 and $2.25 \log$ CFU/g when treated with T1 and T6, respectively. No significant reduction $(p>0.05)$ was observed between T1 and T6, indicating that both coating formulations can be potential candidates as protectors preventing the pineapple slices from contamination. Although the microorganism population does not diminish completely at day 5 of storage, the $\log \mathrm{CFU} / \mathrm{g}$ reductions were 1.71 and 1.3 units for $\mathrm{T} 1$ and $\mathrm{T} 6$, respectively, suggesting that peptide-containing solution (T1) or precipitated peptide (T6) might work as a barrier between the fruit surface and invasive incoming bacteria, improving its protection. These findings correlated with the in vitro results, suggesting the effectiveness of the formulation on pathogen reduction in pineapple slices. Unpredictably, from day 2 in the un-treated pineapple slices (control (-)), some cell counts were detected; this might be due to the internal fruit contamination before harvesting. Though acidic, the pineapple juice at the time of purchasing had a $\mathrm{pH}$ of 3.61 and titratable acidity of $0.78 \%$, expressed as citric acid, and remained stable during storage. A slight increase in $\mathrm{pH}$ (with 0.2 units) was registered in the pineapple slices treated with the pathogenic cocktail and peptide formulations (T1 and T6) at day 5 of storage, suggesting that the refrigeration and acidity does not have major influence in the survival of the pathogenic microorganisms (Figure 3). Moreover, we showed that $E$. coli total cell counts diminished by 2.08 and $2.5 \log \mathrm{CFU} / \mathrm{g}$ in the pineapple slices treated with T1 and T6 formulations at day 5 of storage (Figure 4). In the untreated peptide slices, the E. coli cell counts reduced from $7.8 \mathrm{log}$ $\mathrm{CFU} / \mathrm{g}$ to $7.2 \log \mathrm{CFU} / \mathrm{g}$, indicating that acidity and storage does not influence the survival of E. coli. A significant reduction $(p<0.05)$ of Salmonella versus Shigella cell counts was detected in the pineapple 
slices at day 5 of storage (Figure 5). Based on this study, both CFS and PP formulations are suitable to inhibit a mixture of pathogens in pineapple slices and might be a solution for protection of fruit from contamination.

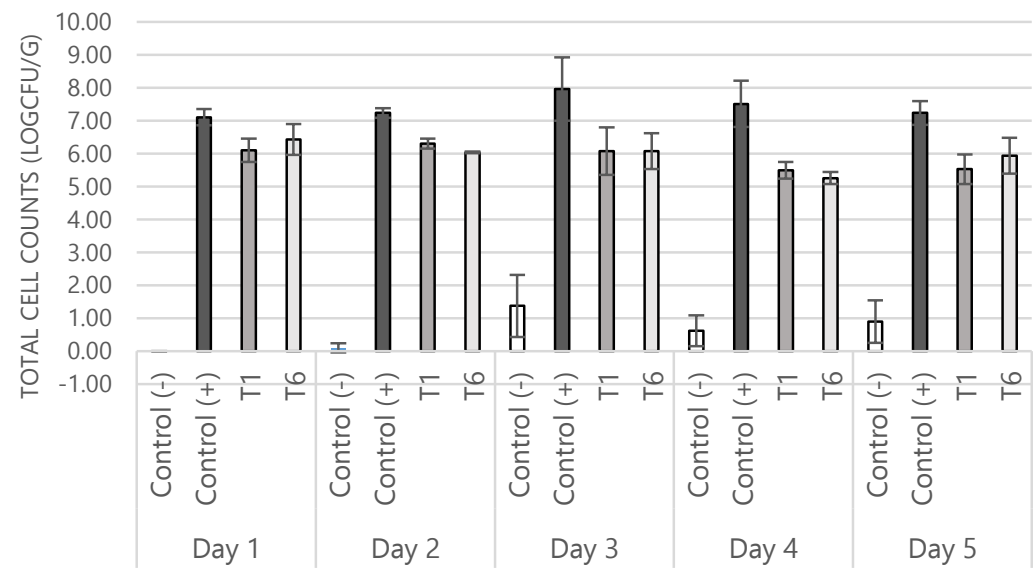

Figure 2. Total cell counts expressed in $\log \mathrm{CFU} / \mathrm{g}$ in the treated and not treated pineapple slides during storage with refrigeration. Legend: Control (-): fruit slices, no pathogens, no peptide; Control (+): fruit slices + indicator cocktail; T1: fruit slices treated with indicator cocktail + formulation T1 (CFS); T6: fruit slices treated with indicator cocktail + formulation T6 (PP); T1: Cys5-4CFS + Gt28CFS:1:1 (v/v); T6: Cys5-4PP + Gt28PP:1:1 (v/v).

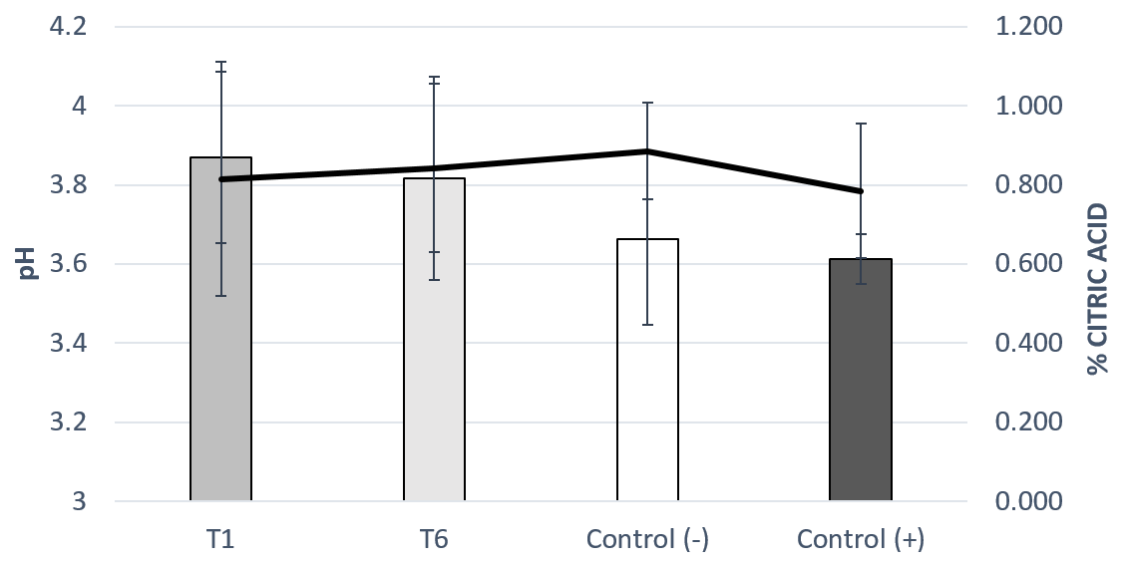

Figure 3. $\mathrm{pH}$ and acidity values (\% of citric acid) registered at day 5 of storage. Legend: Control (-): fruit slices, no pathogens, no peptide; Control (+): fruit slices+ indicator cocktail; T1: fruit slices treated with indicator cocktail + formulation T1 (CFS); T6: fruit slices treated with indicator cocktail + formulation T6 (PP); T1: Cys5-4CFS+ Gt28CFS:1:1 (v/v); T6: Cys5-4PP + Gt28PP:1:1 (v/v). 


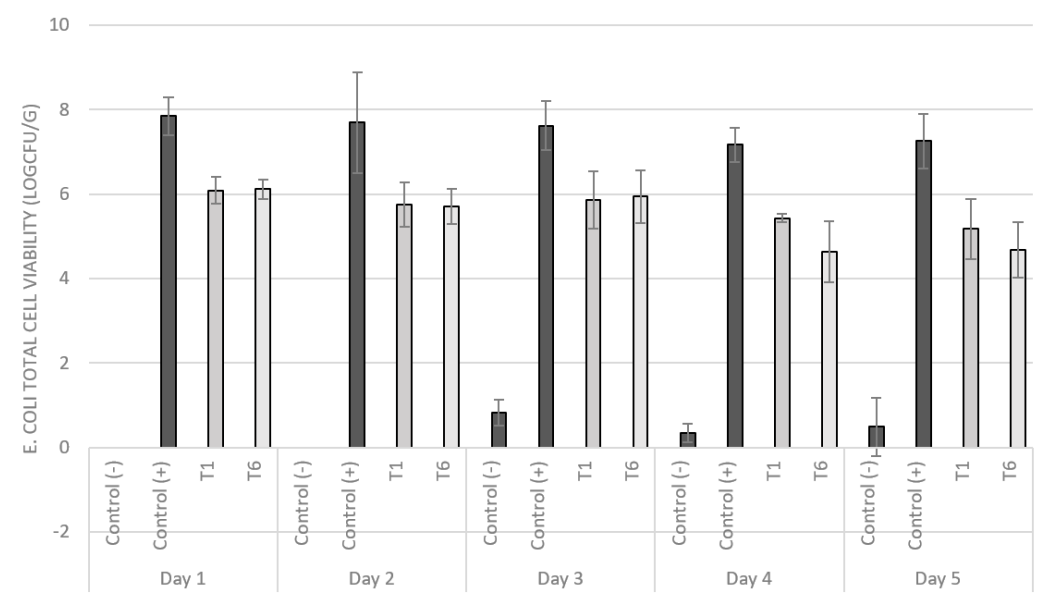

Figure 4. Viability of E. coli strains in pineapple slices treated with peptide-based formulation. Legend: Control (-): fruit slices, no pathogens, no peptide; Control (+): fruit slices+ indicator cocktail; T1: fruit slices treated with indicator cocktail + formulation T1 (CFS); T6: fruit slices treated with indicator cocktail + formulation T6 (PP); T1: Cys5-4CFS + Gt28CFS:1:1 v/v; T6: Cys5-4PP + Gt28PP:1:1 v/v.

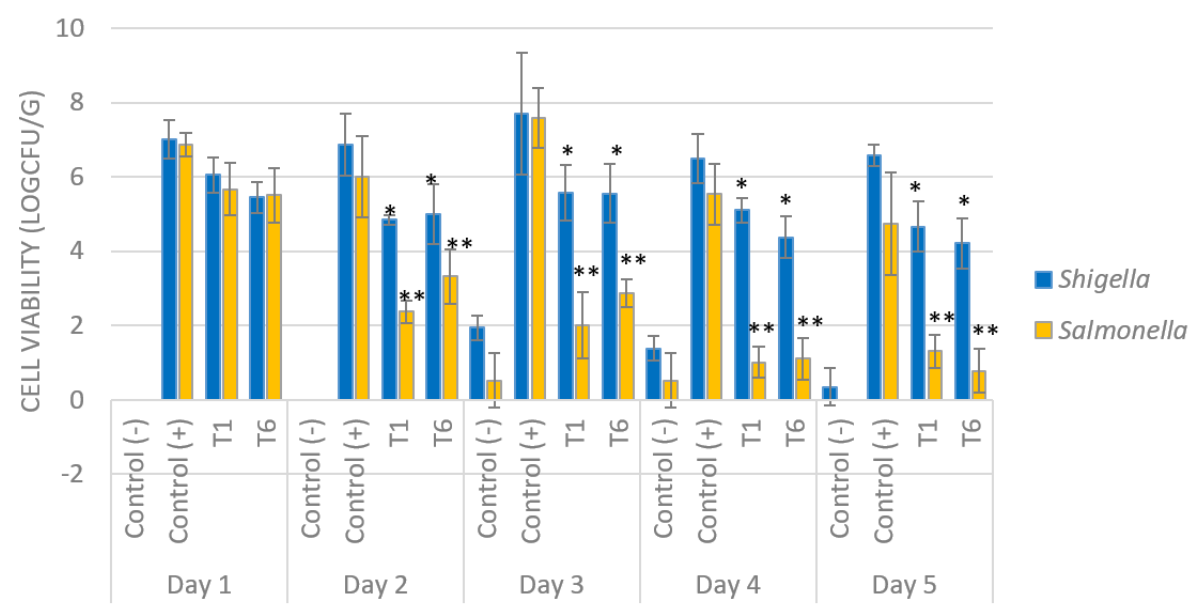

Figure 5. Enumeration of Salmonella and Shigella in the pineapple slices treated and untreated with peptide-based formulations during storage with refrigeration. Legend: Control (-): fruit slices, no pathogens, no peptide; Control (+): fruit slices + indicator cocktail; T1: fruit slices treated with indicator cocktail + formulation T1 (CFS); T6: fruit slices treated with indicator cocktail + formulation T6 (PP); T1: Cys5-4CFS + Gt28CFS:1:1 v/v; T6: Cys5-4PP + Gt28PP::1 v/v. ${ }^{*}, * *$, significant decrease $(p<0.05)$ in cell counts vs. control (+).

\subsection{Peptide-Based Formulation Induced Changes in the Total Protein Profile of the Target Salmonella}

A slightly different protein profile of Salmonella for the untreated (control $(+))$ and samples treated with the T1 and T6 formulations was observed with SDS-PAGE analysis (Figure 6). Although the proteins were not identified, the changes in the expressed one were related to the damaging of the proteins from the cells treated with the peptide-based formulations compared to untreated control. 


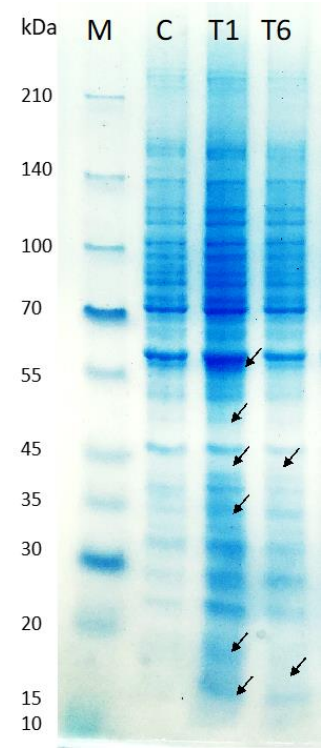

Figure 6. SDS-PAGE study of Salmonella enterica subsp. enterica ATCC51741 whole cell proteins after peptide-based formulation treatment. Legend: C: Salmonella untreated; T1: CFSCys5-4/CFSGt28:1:1 (v/v); T6: PPCys5-4/PPGt28:1:1 (v/v). M: molecular marker (Takara, Clearly Protein Ladder); arrows indicate different bands.

\subsection{Peptide-Based T6 Formulation Induced Cell Death of Salmonella Enterica}

Salmonella enterica subsp. enterica ATCC51741 cell cultures at the exponential growth phase treated with $\mathrm{T} 6$ formulation $(1 \times \mathrm{MIC})$ and untreated control were observed under a transmission electron microscope. The untreated cells showed well-defined cell membranes and a uniform cytoplasm region (Figure 7A), while the bacterial cells treated with $\mathrm{T} 6$ formulation showed cell membrane changes such as membrane disruption, spheroplasts and cytoplasm molecule release or ghost cells (Figure 7B,C), indicating that there is more than one mechanism by which the peptides induce cellular death.

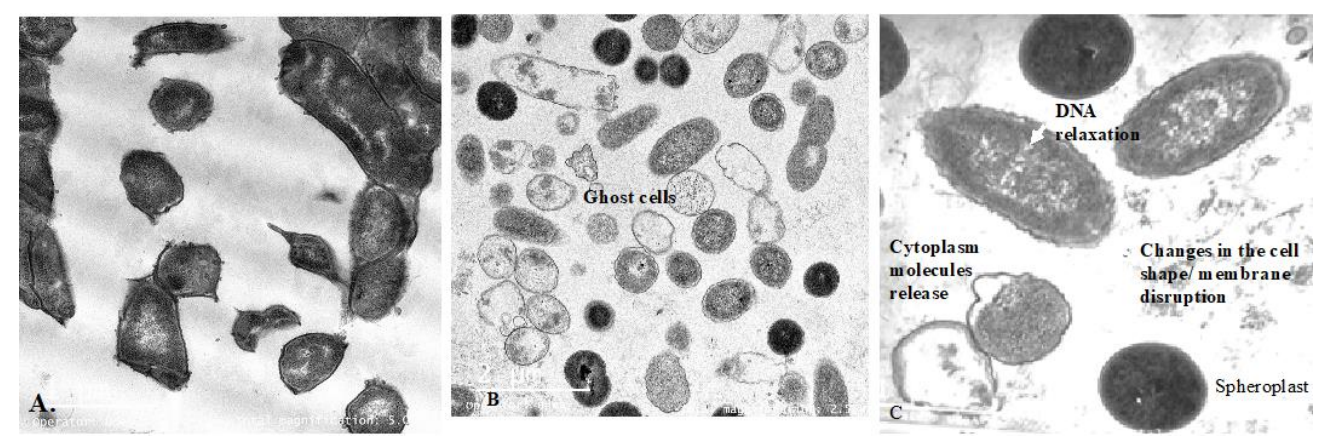

Figure 7. TEM micrograph of Salmonella enterica subsp. enterica untreated (A) and treated with T6 formulation (B,C). Bar $=1,2 \mu \mathrm{m}$.

\section{Discussion}

Street food trade is a common practice in Ecuador, and this traditional practice remains a considerable source of income for the local community [17]. Due to lack of basic infrastructure, such as refrigeration and availability of clean water for washing, the safety of the products sold in these places is compromised, becoming a public health risk for the consumer. Critical points in this food chain involve hygiene practices used during manipulation, food preparation, as well as cooking, storage, service, sanitation and waste management practices [18]. Despite the growth of the food sector, there is no effective improvement in food handling or hygienic control. Among the food products sold in the 
streets, fresh-cut fruits are a suitable microenvironment for the survival of microorganisms. When cut, there is an excessive contact of fruit pulps with the hand during manipulation; therefore, the slices are prone to contamination. Thus, searching for eco-friendly antimicrobial coating substances, such as antimicrobial peptide-based coating formulations to protect the fruit and simultaneously diminish microbial growth, might be a solution to improve food safety. Previously, the bactericidal activity of individual CFSCys5-4 and CFSGt28 towards E. coli and Salmonella was previously investigated in vitro; Cys5-4 was more effective towards E. coli compared to Salmonella and Shigella [19], while CFSGt28 inhibited completely the growth of Salmonella at both the vegetative and exponential phases of growth, suggesting its bactericidal mode of action [14]. The effect on multiple targets that competed for the same microenvironment might depend on the innate resistance of the target, the combination of the peptides, their form of application (CFS vs. PP), the doses or the synergic effect of acids and secreted peptides likewise might facilitate the translocation of peptides through the target cell wall [20]. It has been reported that bacteriocins from various LAB species incorporated in active food packaging had inhibitory capacity in vitro towards foodborne pathogenic bacteria [21]. Nonetheless, the effect of peptides on simultaneously inhibiting the growth multiple target bacteria was not well investigated. The present study indicated that the edited antimicrobial formulations applied as cell-free supernatant and precipitated peptides had the capacity to diminish simultaneously the cell counts of a bacterial mixture in vitro (Figure 1); thus, they are promising candidates for use as antimicrobial solutions in foods such as fresh-cut fruits.

The antimicrobial resistance developed by various microorganisms became a more serious issue in the food industry because food products were found to be contaminated during transportation and storage. On the other hand, their persistence in food represents a source of spreading antibiotic resistance; thus, the application of novel antimicrobial agents based on peptides produced by lactic bacteria might represent a better solution. Although food products of animal origin are considered the main source of diseases transmitted by contaminated food, fresh-cut fruits and their juices are becoming a current concern. Consumption of fresh-cut fruits, even those as acidic as pineapple, may have health implications as the pathogens are antibiotic resistance carriers. Early research demonstrated that pathogenic bacteria such as E. coli O157:H7 can survive well in acidic pineapple juice at different incubation temperatures and could grow in fruit juices with relatively high $\mathrm{pH}$ values (5.7) when stored at ambient and refrigeration temperatures [22]. The efficacy of Cys5-4 applied independently as CFS or PP was investigated in natural orange juice or raw meat [13,19]; on the other hand, Gt28 peptides inhibited Salmonella enterica subsp. enterica ATCC51741 cells at $3 \mathrm{~h}$ of incubation, indicating its bacteriolytic mode of action in vitro [14]. Thus, we address the question if the selected formulations based on a mixture of peptides produced by different lactic bacteria might enhance the inhibitory potential by simultaneously decreasing multiple target pathogenic bacteria in fresh-cut pineapple slices. It has been reported that several LAB strains from Leuconostoc spp. and L. plantarum were able to strongly inhibit the growth of foodborne human pathogens on golden delicious apples [23]. A reduction of about $1 \log \mathrm{CFU} / \mathrm{g}$ was obtained when apple wedges were inoculated with L. rhamnosus GG [24], while by applying cells of L. plantarum B2 and L. fermentum PBCC11.5 on fresh-cut pineapple, a reduction of E. coli O157:H7 was observed [25]. In our study, a reduction of multiple pathogenic strains (five) was observed when treated with $\mathrm{T} 1$ and T6 edited formulations, indicating their efficiency in controlling the pathogenic growth during storage (Figure 2). The increased cell counts at day 5 might be related to the resistance developed by the target over time; the growth on cells in negative control samples was related to the pre-existing core fruit contamination not visible at the time of purchasing. We observed similar phenomena previously in tomato fruits [12]. The reduction of the cell counts does not correlate with the enhancing of $\mathrm{pH}$ during storage after the application of formulation, indicating that the cell count reduction depended upon the presence of peptide or acidity (Figure 3). Peptides produced by lactic acid bacteria are positively charged substances with hydrophobic moieties; their interactions with negatively charged phosphate groups on the microbial cell membrane can allow rapid binding and insertion into the membrane and generate pores [26]. Generally, strong 
antimicrobial activity against one or two indicator bacteria applied independently in the food matrix is not sufficient; thus, editing formulations with a mix of peptides would enhance the simultaneous death of more than one target bacterium. The peptide formulations in this study showed the capacity to diminish Salmonella, Shigella and E. coli in pineapple slices artificially infected with a pathogenic cocktail (Figures 4 and 5). Perhaps the antimicrobial peptide mixture acts as provoking molecules causing inhibition of macromolecule synthesis; an early study indicated a synergistic action with the host innate immune mechanisms [27]. The peptide-based formulations induced changes in the protein profile of Salmonella, suggesting that they may damage the integrity of the cell membrane, thereby eventually inhibiting the growth and reproduction of bacterial cells (Figure 6). Based on the SDS-PAGE result, we suggested that the peptides accumulated at the cytoplasmic membrane induce ruptures of the protein structure of the target bacterium, thus contrary to the classic antibiotics interaction with the cytoplasmic membrane inducing its permeabilization. The peptides used in this study belong to two-peptide class bacteriocins; Cys5-4 produced plantaricin W and Gt28 produced lacticin 3147, lactococcin M and lactococcin A [14,15]. In this sense, they might exert a bacteriolytic mode of action by inducing damage of the outer cell membrane after inserting into the cytoplasmic membrane lipid bilayer, leading to the disruption of the membrane by permeabilization and loss of integrity, followed by cellular death [28]. In another study, a changed in the total protein profile of E. coli cells was obtained after application of synthetic bactericidal agent zinc oxide nanoparticles [29]. Similarly, sericin-based hydrogel blocked the expression of some E. coli proteins when incubated for $12 \mathrm{~h}$, accelerating the leakage of total sugars from the bacterial cytoplasm [30]. Nevertheless, in the treatment with $1 \times$ MIC of the peptide formulation in the present study, the ghost cells and spheroplasts were detected in the TEM micrographs, indicating that the cell membrane was damaged and the cytoplasmic cell contents were released (Figure 7). Spheroplasting has been reported in bacteria treated with chloramphenicol, oxytetracycline, kanamycin, streptomycin and tobramycin. Ghost cells maintain their cellular morphology similar to native untreated peptide bacteria where the entire cell surface remains intact, but all cellular components are released. It has been shown that ghost cells, describing the lysed bacterial cell, emerged following the treatment with ciprofloxacin, norfloxacin or gentamicin and erythromycin [31,32]. The ghost cell formation after treating Salmonella with peptides was recently detected [28]. To the best of our knowledge, this is the first report indicating a Salmonella killing event of two-peptide bacteriocins. Ultrastructural and morphological changes in Salmonella cells indicated that some peptides share a multiple action mechanism, and its elucidation will be more effective for bio-preservation.

\section{Conclusions}

Taken together, the edited coating formulations simultaneously diminish multiple target microorganism growth in pineapple slices, demonstrating their bacteriolytic mode of action and contributing to carrying a protective effect. Coating with peptide-based suspension proved to be a promising approach to control bacterial growth in fresh-cut pineapple fruits, thus enhancing the safety of food products. Nonetheless, the antimicrobial substances produced by lactic acid bacteria added as cell-free supernatant or precipitated peptides, as a protective culture in preservation of fresh-cut fruits, need further research, but they can be considered as a sustainable option for preservation of minimally processed food.

Author Contributions: Conceptualization, G.N.T.; methodology, G.N.T.; software, D.O.; validation, C.O. and D.O.; formal analysis, G.N.T. and D.O.; investigation, G.N.T., D.O. and C.O.; resources, G.N.T. and D.O.; data curation, G.N.T.; writing — original draft preparation, G.N.T.; writing—review and editing, G.N.T.; visualization, G.N.T.; supervision, G.N.T.; project administration, G.N.T.; funding acquisition, G.N.T.; All authors have read and agreed to the published version of the manuscript.

Funding: This work was supported by the Centre or Research (CUICYT) of the Technical University of the North, Grant No. 2416/2018 and 2929/2019. 
Acknowledgments: I express my gratitude to Ing. E. Pita for technical support and P. Reyes and J. Suarez for helping with the experiments. The authors thank D. Brown for helpful comments and the correction of the manuscript.

Conflicts of Interest: The authors declare no conflict of interest.

\section{References}

1. Ratti, M.F.; Ascunce, M.S.; Landivar, J.J.; Goss, E.M. Pineapple heart rot isolates from Ecuador reveal a new genotype of Phytophthora nicotianae. Plant Pathol. 2018, 67, 1803-1813. [CrossRef]

2. Nassr, M.S.; Abu-Naser, S.S. Knowledge based system for diagnosing pineapple diseases. Int. J. Acad. Pedag. Res. IJAPR 2018, 2, 12-19.

3. Abarca, L.F.M. Producción y rendimiento del cultivo de la piña (Ananas comosus) en Costa Rica periodo 1984-2014. Rev. E Agroneg. 2018, 4. [CrossRef]

4. Lal Basediya, A.; Samuel, D.; Beera, V. Evaporative cooling system for storage of fruits and vegetables-A review. J. Food Sci. Technol. 2013, 50, 429-442. [CrossRef]

5. Nazuka, E.; Inatsu, Y.; Kayasaki, S.; Miyamaru, M. The investigation of bacterial contamination in fresh-cut fruits, and the behavior of Escherichia coli O157: H7 and Salmonella enteritidis on fruit cubes. Jpn. J. Food Microbiol. 2004, 21, 269-274. [CrossRef]

6. Adam, E.; Groenenboom, A.; Kurm, V.; Rajewska, M.; Schimdt, R.; Tyc, O.; Weidner, S.; Berg, G.; de Boer, W.; Falcao Salles, J. Controlling the microbiome: Microhabitat adjustments for successful biocontrol strategies soil and human gut. Front. Microbiol. 2016, 7, 1079. [CrossRef]

7. Yigeremu, B.; Bogale, M.; Mogessie, A. Fate of Salmonella species and E. coli in fresh-prepared orange, avocado, papaya and pineapple juices. Ethiop. J. Health Sci. 2001, 11, 89-95.

8. Delves-Broughton, J. Use of the natural food preservatives, nisin and natamycin, to reduce detrimental thermal impact on product quality. In In-Pack Processed Foods Improving Quality; Series in Food Science, Technology and Nutrition; Woodhead Publishing: Cambridge, UK, 2008; pp. 319-337. [CrossRef]

9. Olvera-García, Y.; Serrano-Maldonado, C.E.; Quirasco, M. Detección de proteínas con actividad antibacteriana producidas por bacterias ácido lácticas. Biotecnología 2015, 19, 25-43.

10. Wong, C.B.; Khoo, B.Y.; Sasidharan, S.; Piyawattanametha, W.; Kim, S.H.; Khemthongcharoen, N.; Ang, M.Y.; Chuah, L.O.; Liong, M.T. Inhibition of Staphylococcus aureus by crude and fractionated extract from lactic acid bacteria. Benef. Microbes 2015, 6, 129-140. [CrossRef]

11. Li, D.; Ni, K.; Pang, H.; Wang, Y.; Cai, Y.; Jin, Q. Identification and antimicrobial activity detection of lactic acid bacteria isolated from corn stover silage. Asian Australas. J. Anim. Sci. 2015, 28, 620-631. [CrossRef]

12. Tenea, G.N.; Pozo Delgado, T. Antimicrobial peptides from Lactobacillus plantarum UTNGt2 prevent harmful bacteria growth on fresh tomatoes. J. Microbiol. Biotechnol. 2019, 29, 1553-1560. [CrossRef] [PubMed]

13. Tenea, G.N.; Guana, J.M. Inhibitory substances produced by native Lactobacillus plantarum UTNCys5-4 control microbial population growth in meat. J. Food Qual. 2019, 9516981. [CrossRef]

14. Tenea, G.N.; Hurtado, P.; Ortega, C. Inhibitory effect of substances produced by native Lactococcus lactis strains of tropical fruits towards food pathogens. Prev. Nutr. Food Sci. 2018, 23, 260-268. [CrossRef] [PubMed]

15. Tenea, G.N.; Lara, I.M. Antimicrobial compounds produced by Weissella confusa Cys2-2 strain inhibit gram-negative bacteria growth. CyTA J. Food 2019, 17, 105-111. [CrossRef]

16. Kim, S.Y. Production of fermented kale juices with Lactobacillus strains and nutritional composition. Prev. Nutr. Food Sci. 2017, 22, 231-236. [CrossRef]

17. Campos, J.; Gil, J.; Mourao, J.; Peixe, L.L.; Antunes, P. Ready-to-eat street-vended food as a potential vehicle of bacterial pathogens and antimicrobial resistance: An exploratory study in Porto region, Portugal. Int. J. Food Microbiol. 2015, 206, 1-6. [CrossRef]

18. Food and Agriculture Organization (FAO); International Fund for Agricultural Development (IFAD); United Nations Children's Fund (UNICEF); World Food Programme (WFP); World Health Organization (WHO). The State of Food Security and Nutrition in the World: Building Resilience for Peace and Food Security; FAO, Ed.; Food and Agriculture Organization of the United Nations (FAO), 2017; p. 132. Available online: http://www.fao.org/3/a-I7695e.pdf (accessed on 20 January 2020).

19. Tenea, G.N.; Barrigas, A. The efficacy of bacteriocin-containing cell-free supernatant from Lactobacillus plantarum Cys5-4 to control pathogenic bacteria growth in artisanal beverages. Int. Food Res. J. 2018, 25, 2131-2137. 
20. Hartmann, H.A.; Wilke, T.; Erdmann, R. Efficacy of bacteriocin-containing cell-free culture supernatants from lactic acid bacteria to control Listeria monocytogenes in food. Int. J. Food Microbiol. 2011, 146, 192-199. [CrossRef]

21. Khaneghah, A.M.; Hashemi, S.M.B.; Limbo, S. Antimicrobial agents and packaging systems in antimicrobial active food packaging: An overview of approaches and interactions. Food Bioprod. Process. 2018, 111, 1-19. [CrossRef]

22. Mutaku, I.; Erku, W.; Ashenafi, M. Growth and survival of Escherichia coli O157: H7 in fresh tropical fruit juices at ambient and cold temperatures. Int. J. Food Sci. Nutr. 2005, 56, 133-139. [CrossRef]

23. Trias, R.; Baneras, L.; Badosa, E.; Montesinos, E. Bioprotection of golden delicious apples and Iceberg lettuce against foodborne bacterial pathogens by lactic acid bacteria. Int. J. Food Microbiol. 2008, 123, 50-60. [CrossRef] [PubMed]

24. Alegre, I.; Vinas, I.; Usall, J.; Anguera, M.; Abadias, M. Microbiological and physicochemical quality of fresh-cut apple enriched with the probiotic strain Lactobacillus rhamnosus GG. Food Microbiol. 2011, 28, 59-66. [CrossRef] [PubMed]

25. Russo, P.; de Chiara, M.L.V.; Vernile, A.; Amodio, M.L.; Arena, M.P.; Capozi, V.; Masa, S.; Spano, G. Fresh-Cut pineapple as a new carrier of probiotic lactic acid bacteria. BioMed Res. Int. 2014, 301983. [CrossRef] [PubMed]

26. Cleveland, J.; Montville, T.J.; Nes, I.F.; Chikindas, M.L. Bacteriocins: Safe, natural antimicrobials for food preservation. Int. J. Food Microbiol. 2001, 71, 1-20. [CrossRef]

27. Sharma, S.S.; Singh, R.; Rana, S. Bioactive peptides: A review. Int. J. Bioautom. 2011, 15, 223-250.

28. Tenea, G.N. Peptides from native lactic acid bacteria of tropical fruits kill Salmonella enterica through multiple action mechanisms. Helyion. under review.

29. Pérez Parra, J.; Useche Castro, L.; Isea León, F.; Cuello Pérez, M.; Canchingre Bone, E. Damage of lipopolysaccharides in outer cell membrane and production of ROS-mediated stress within bacteria makes nano zinc oxide a bactericidal agent. Appl. Nanosci. 2015, 5, 857. [CrossRef]

30. Xue, R.; Liu, Y.; Zhang, Q.; Liang, C.; Qin, H.; Liu, P.; Wang, K.; Zhang, X.; Chen, L.; Wei, Y. Shape changes and interaction mechanism of Escherichia coli cells treated with sericin and use of a sericin-based hydrogel for wound healing. Appl. Environ. Microbiol. 2016, 82, 4663-4672. [CrossRef]

31. Riley, M.A.; Wertz, J.E. Bacteriocins: Evolution, ecology, and application. Annu. Rev. Microbiol. 2002, 56, 117-137. [CrossRef]

32. Wojnicz, D.; Kłak, M.; Adamski, R.; Jankowski, S. Influence of subinhibitory concentrations of amikacin and ciprofloxacin on morphology and adherence ability of uropathogenic strains. Folia Microbiol. 2007, 52, 429-436. [CrossRef]

(C) 2020 by the authors. Licensee MDPI, Basel, Switzerland. This article is an open access article distributed under the terms and conditions of the Creative Commons Attribution (CC BY) license (http://creativecommons.org/licenses/by/4.0/). 